\title{
Political and government connections on corporate boards in Australia: Good
}

\section{for business?}

Type: Article

\section{Abstract:}

While prior studies document the benefits of political connections in emerging markets, their value in developed markets is less certain. In this study, we examine the types of firms that have directors with political and government connections on their boards and the value of these connections to shareholders in Australia, a developed market with low levels of corruption and lobbying, and public funding of election campaigns. We find that directors with political and government connections hold $2.1 \%$ of listed company directorships (in $7.7 \%$ of listed companies) in Australia. After controlling for director and firm characteristics, we find the market reaction to the appointment of directors with political and government connections is significantly lower than other directors. This is particularly the case for former politicians whose political parties are not in power and who have less political experience. In summary, we find no evidence that political and government connections on corporate boards are particularly abundant or valuable to shareholders in Australia.

\begin{tabular}{|c|l|}
\hline Author & $\begin{array}{r}\text { a) Gray S., } \\
\text { b) Harymawan I., } \\
\text { c) Nowland J. }\end{array}$ \\
\hline Source & Australian Journal of Management \\
\hline ISSN & 03128962 \\
\hline DOI & $10.1177 / 0312896214535788$ \\
\hline Volume (Issue) & $41(1)$ \\
\hline Page & $3-26$ \\
\hline Year & 2016 \\
\hline
\end{tabular}

Keyword:

D72, G14, G34

Please Cite As:

Gray, S., Harymawan, I., \& Nowland, J. (2016). Political and government connections on corporate boards in australia: Good for business? Australian Journal of Management, 41(1), 3-26.

URL: 
$84992885989 \&$ doi $=10.1177 \% 2 f 0312896214535788 \&$ partnerlD $=40 \& m d 5=$ ca8 8f8a22ca5098c78adb33639d8e6f2

- https://journals.sagepub.com/doi/10.1177/0312896214535788 